\title{
Straight deep hypothermic circulatory arrest for aortic arch surgery: Going the way of the dinosaurs?
}

\author{
Nicholas T. Kouchoukos, MD
}

\author{
From the Division of Cardiovascular and Thoracic Surgery, Missouri Baptist Medical Center, BJC HealthCare, St \\ Louis, Mo. \\ Disclosures: Author has nothing to disclose with regard to commercial support. \\ Received for publication Aug 18, 2017; accepted for publication Aug 18, 2017; available ahead of print Sept 15, \\ 2017. \\ Address for reprints: Nicholas T. Kouchoukos, MD, Division of Cardiovascular and Thoracic Surgery, 3023 N \\ Ballas Rd, Suite 150D, St Louis, MO 63131 (E-mail: ntkouch@aol.com). \\ J Thorac Cardiovasc Surg 2017;154:1840-1 \\ $0022-5223 / \$ 36.00$ \\ Copyright (c) 2017 by The American Association for Thoracic Surgery \\ http://dx.doi.org/10.1016/j.jtcvs.2017.08.044
}

In this issue of the Journal, Damberg and colleagues ${ }^{1}$ report their experience with straight deep hypothermic circulatory arrest (DHCA) as the sole means of brain protection during operations on the aortic arch in 613 consecutive patients, focusing on late outcomes. ${ }^{1}$ The independent variables associated with increased 1-year mortality were acute type A aortic dissection, reoperative status, and the presence of descending thoracic aortic pathology. The independent variables associated with increased mortality beyond 1 year were increased age, postoperative complications (stroke, dialysis, pulmonary complications), and postoperative atrial fibrillation. The duration of DHCA did not emerge as a significant predictor of either 1-year or late mortality. Damberg and colleagues ${ }^{1}$ conclude that aortic arch surgery with DHCA can be performed with favorable early and late survivals and that the length of DHCA has only limited impact on these outcomes.

Elefteriades and his colleagues at Yale are perhaps the most impassioned (and persistent) advocates of straight DHCA for operations involving the aortic arch, and they have used no other alternative or adjunctive strategy for brain protection since at least 2003 . Their early outcomes, in terms of mortality and overt neurologic injury, are impressive $(2.9 \%$ operative mortality, $2 \%$ stroke rate). The low prevalences of reoperations for bleeding, pulmonary complications, prolonged ventilation, and renal replacement therapy should provide reassurance to the users of this technique that when it is applied in a systematic fashion, the rates of mortality and morbidity are comparable to those achieved with other commonly used techniques, including moderate hypothermia with antegrade brain perfusion.

Although Damberg and colleagues ${ }^{1}$ did not identify use of DHCA as an independent predictor of either 1-year or late mortality, there are concerns related to this finding regarding stroke and other indicators of neurologic injury. The stroke rate was $10.5 \%$ for patients with a DHCA time of 50 minutes or longer, versus $1.7 \%$ for those with a DHCA time shorter than 50 minutes, a 6-fold difference

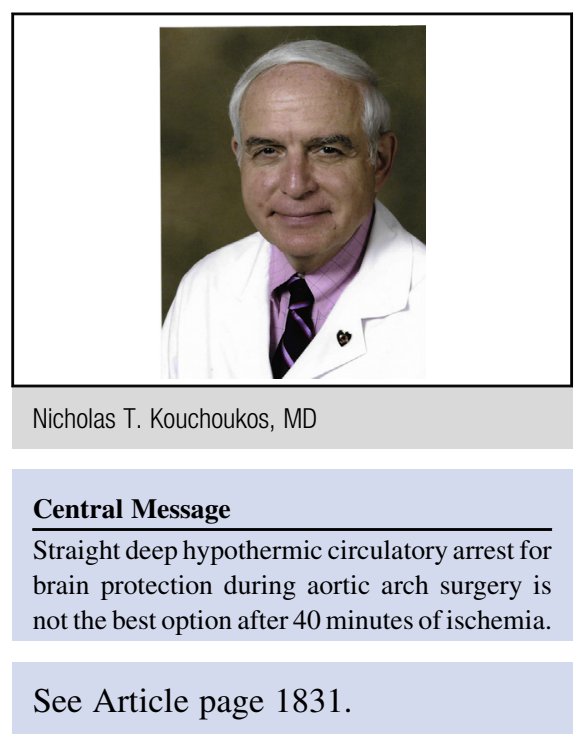

with a $P$ value of .05 . Temporary neurologic dysfunction and seizures, less sensitive but likely indicators of neurologic injury, 2,3 occurred in $5.1 \%$ and $1 \%$ of the patients, respectively, but they were not analyzed further. It should also be noted that among the patients in whom the duration of DHCA was 40 minutes or longer, the operative mortality was $4.5 \%, 4$ times higher than the mortality for the patients with a DHCA time of less than 40 minutes $(1.1 \%)$, although the difference did not reach statistical significance.

Although there is no consensus, there is agreement among most aortic surgeons, including the same Yale group, ${ }^{4}$ that 40 minutes is the upper limit of safety when using DHCA. It is therefore concerning that, with the availability of other strategies for neuroprotection during extensive operations on the aortic arch (namely antegrade brain perfusion) and with knowledge of the adverse effects on neurologic function with the longer arrest times that were observed in this study, Damberg and colleagues ${ }^{1} \mathrm{did}$ not initiate brain perfusion either initially, when a prolonged and complicated procedure was anticipated, or when the DHCA time approached 40 minutes.

That said, Damberg and colleagues ${ }^{1}$ have provided solid evidence that DHCA is a safe and effective method of brain protection for procedures involving the aortic arch if the duration of circulatory arrest does not exceed 40 minutes. It continues to be the method of choice for many surgeons who perform partial arch procedures, myself included, and it is likely to remain so. ${ }^{5}$ Will straight deep hypothermic 
circulatory arrest for aortic arch operations eventually go the way of the dinosaurs in favor of other techniques with antegrade brain perfusion? Not any time soon.

\section{References}

1. Damberg A, Carino D, Charilaou P, Peterss S, Tranquilli M, Ziganshin BA, et al. Favorable late survival after aortic surgery under straight deep hypothermic circulatory arrest. J Thorac Cardiovasc Surg. 2017:154:1831-9.

2. Ergin MA, Uysal S, Reich DL, Apaydin A, Lansman SL, McCullough JN, et al. Temporary neurological dysfunction after deep hypothermic circulatory arrest: a clinical marker of long-term functional deficit. Ann Thorac Surg. 1999;67: 1887-90; discussion 1891-4.

3. Krähenbühl ES, Immer FF, Stalder M, Englberger L, Eckstein FS, Carrel TP. Temporary neurological dysfunction after surgery of the thoracic aorta: a predictor of poor outcome and impaired quality of life. Eur J Cardiothorac Surg. 2008;33: 1025-9.

4. Ziganshin BA, Rajbanshi BG, Tranquilli M, Fang H, Rizzo JA, Elefteriades JA Straight deep hypothermic circulatory arrest for cerebral protection during aortic arch surgery: safe and effective. J Thorac Cardiovasc Surg. 2014;148:888-98; discussion 898-900.

5. Ziganshin BA. Which method of cerebral protection do you prefer to use for aortic arch surgery? Aorta (Stamford). 2013;1:69-70.

Access to The Journal of Thoracic and Cardiovascular Surgery Online is reserved for print subscribers!

Full-text access to The Journal of Thoracic and Cardiovascular Surgery Online is available for all print subscribers. To activate your individual online subscription, please visit The Journal of Thoracic and Cardiovascular Surgery Online, point your browser to http://www.mosby.com/jtcvs, follow the prompts to activate your online access, and follow the instructions. To activate your account, you will need your subscriber account number, which you can find on your mailing label (note: the number of digits in your subscriber account number varies from 6 to 10). See the example below in which the subscriber account number has been circled:

\section{Sample mailing label}

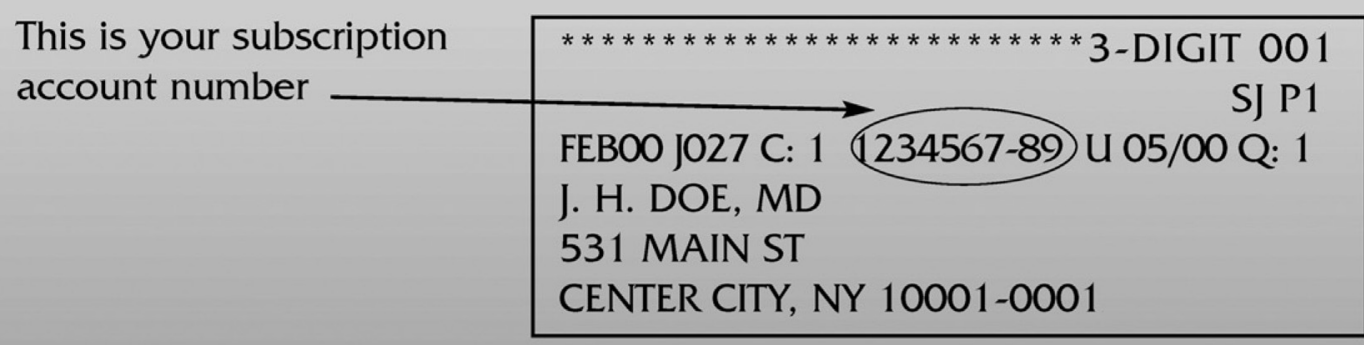

Personal subscriptions to The Journal of Thoracic and Cardiovascular Surgery Online are for individual use only and may not be transferred. Use of The Journal of Thoracic and Cardiovascular Surgery Online is subject to agreement to the terms and conditions as indicated online. 